\title{
Malta and the Nineteenth Century Grain Trade: British free trade in a microcosm of Empire? ${ }^{1}$
}

\author{
Paul Sharp \\ Department of Economics, University of Copenhagen.
}

\begin{abstract}
It is often assumed that Britain's colonies followed the British doctrine of free trade in the second half of the nineteenth century. Malta, which became a British colony in 1814, did indeed become an early free trader. However, she failed to liberalize the grain trade, even when the mother country famously repealed the Corn Laws. This paper documents that although institutions changed over the years, the ad valorem equivalents of the duties on wheat did not. The reason for this seems to be that administrators were convinced that is was not possible to fund government spending in any other way. The duties on grain in Malta were therefore not protectionist, but rather for revenue purposes, in contrast to the UK Corn Laws. Taxing an inelastic demand for foreign wheat by Maltese, who were unable to grow enough food to support themselves, was certainly an effective way of raising revenue, but probably not the fairest one, as contemporaries were well aware.
\end{abstract}

\section{Introduction}

When the Knights of the Order of St. John of Jerusalem were offered Malta as their new headquarters by Charles V of Spain in 1524, they sent a Commission to investigate. They concluded that "Malta was little more than a rock inadequately covered with soil, its main products being cotton, honey and cumin, which were exchanged for corn". 2 However, having been forced out of Jerusalem hundreds of years earlier, and having moved from place to place since then, they nevertheless made the island their home.

Although it is true that Malta is a small island with thin, rocky and dry soils, its population nevertheless flourished under the knights, who brought with them substantial income from property, in particular in France, and the Maltese population was able to grow to a level whereby it was almost totally dependent on outside sources of food.

Malta was, then, a country with a clear comparative disadvantage in agriculture and was heavily dependent on imports from abroad. Nevertheless, the knights continued a

\footnotetext{
${ }^{1}$ I would like to thank Jeanet Bentzen, Ingrid Henriksen, Markus Lampe, Sonja Lohmann, Karl Gunnar Persson, seminar participants and anonymous referees for suggestions and advice. In particular I would like to thank Jacob Weisdorf, who inspired this work.

2 Pirotta, G., The Maltese Public Service 1800-1940: The Administrative Politics of a Micro-State, Malta, 1996, 21.
} 
system whereby the government was heavily dependent on a tax on imported grains. This seeming paradox might, however, have been expected to come to an end with the arrival of new rulers in the nineteenth century. The British soon came to be associated with a free trade philosophy which swept Europe in the second half of the nineteenth century, and was to usher in the first era of globalization. ${ }^{3}$

Indeed, the British colonies have often been assumed to have simply followed in their master's footsteps in terms of trade liberalization. However, although Malta liberalized her tariff system a decade before the repeal of the Corn Laws in the UK, she thereafter remained a small island of high agricultural duties in a European sea of free trade in the second half of the nineteenth century. And this despite the seeming futility of remaining so given her dependence on foreign supplies.

This paper takes a look at the history of grain tariffs in Malta until the end of the nineteenth century. More specifically, the available evidence on the institutional changes in Malta is pieced together and ad valorem equivalents (AVEs) of the annual duties collected on wheat are calculated and compared with those found for the UK by Sharp ${ }^{4}$. The level of Maltese AVEs were comparable to those in the UK in the first half of the nineteenth century. Despite an early move to free trade, however, they continued at their historical level after the UK repeal of the Corn Laws and the movement to free trade in the rest of Europe.

\section{The history of the Maltese regulation of the wheat trade}

The knights established a grain monopoly, which bought wheat and sold it at a fixed price. The British allowed this to continue until 1822, when wheat imports by private interests were permitted. Figure 1 shows the increase in the imports of wheat into Malta from shortly after the abolition of the monopoly.

\footnotetext{
${ }^{3}$ O'Rourke, K.H. and Williamson, J.G., Globalization and History, London, 1999.

${ }^{4}$ Sharp, P.R., 1846 and All That: The Rise and Fall of British Wheat Protection in the Nineteenth Century, Department of Economics, University of Copenhagen Discussion Paper, 6-14.
} 


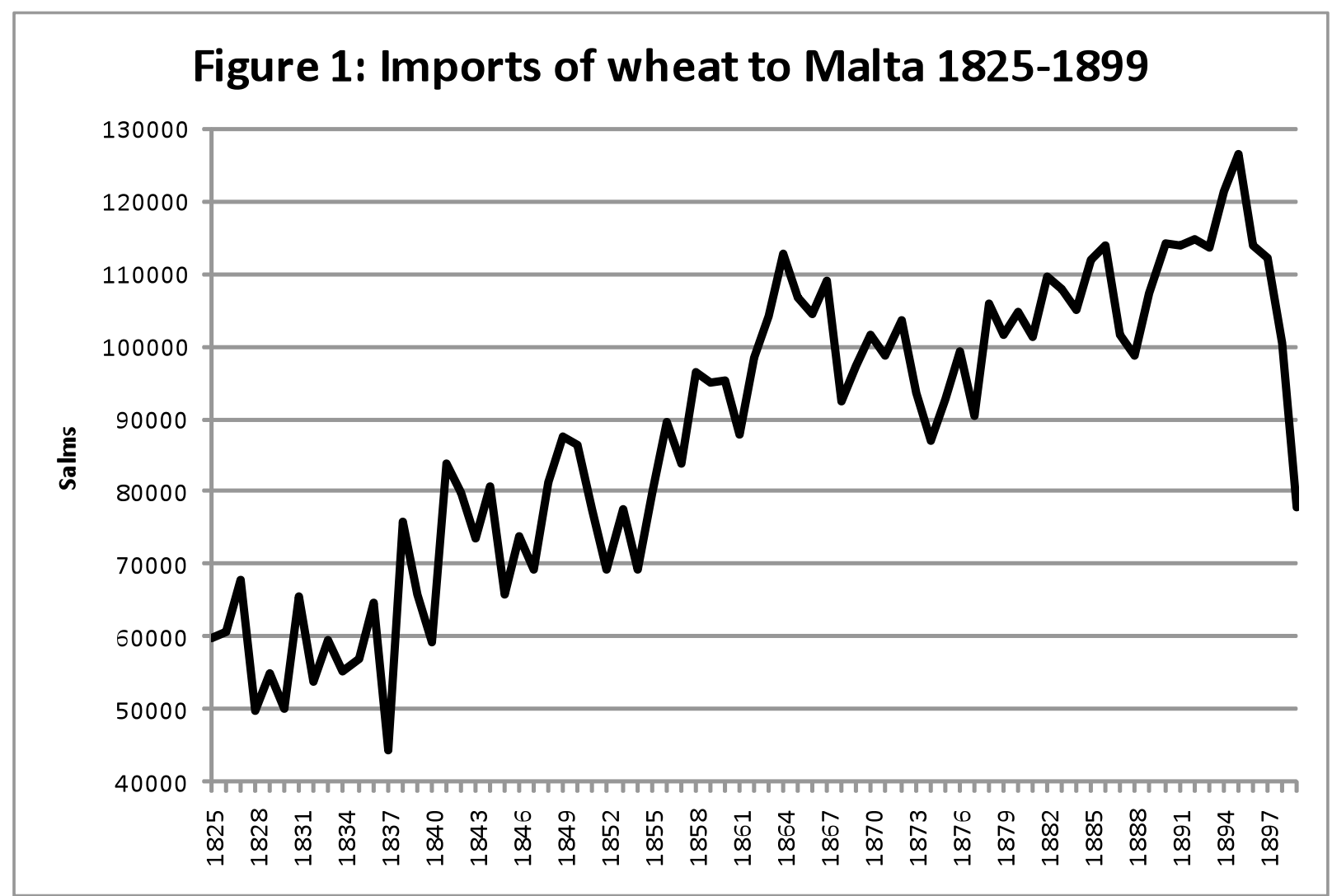

Sources: BPP(various). The figures are actually for wheat released from bond for consumption, which is when the duty was payable, and not imports as such.

The picture is one of growth, but this is almost certainly attributable to the growth of the population. The abolition of the monopoly did not mean a free trade in wheat. In fact, during all the period illustrated, the trade was restricted by high duties.

\subsection{Under the Knights}

As was common in preindustrial times ${ }^{5}$, the government of Malta was heavily involved in the regulation of the supply of grain, and under the Knights the Grandmaster really was the "baker of last resort". The importation of wheat was governed by a state monopoly, the Università of Valletta, which took over from the Università of Mdina with the granting of Malta to the Knights of St. John of Jerusalem in perpetual fief in 1530.

The Università was originally a form of local government, first established in 1397, but under the knights it became almost exclusively involved with the management of the grain trade and administration of the massa frumentaria, or grain fund. The Università of Valletta had a monopoly on the importation of wheat, but it also imported other goods,

\footnotetext{
${ }^{5}$ Persson, K.G., Grain Markets in Europe 1500-1900: Integration and Deregulation, Cambridge, 1999.
} 
such as oil, cattle and tobacco. Moreover, it controlled the markets by fixing the price of wheat, as well as by administering the system of weights and measures and controlling quality. The Università also became a form of public bank, receiving private capital to finance its operations. Although wheat was exempt from direct duty, the difference between the purchase and selling price amounted to an indirect tax on consumers, since part of the revenue raised went to pay interest on loans raised by the Università from private sources. ${ }^{6}$ The Università sold wheat at a set price to the millers, thus ensuring that the price of bread was constant for many years. As the world price of wheat fluctuated, so too did the losses and gains, whilst the population was shielded from the effects of this. This system was a product of unstable times, when the Knights were concerned with ensuring adequate supplies for the population at a time of piracy and frequent international conflicts. In this it was successful, but on the other hand it also inflated the price of wheat, due to the institutional demands of the grain monopoly, which had to both purchase wheat and distribute it locally.

The Knights exercised almost complete control over the Università, and they understood two important benefits of doing so, which the British were later to exploit. First, any rebellion against the Order could easily be crushed, since they controlled all the grain supplies. Second, keeping the people well fed would avoid political agitation provoked by the nobility they had displaced. ${ }^{7}$

The confiscation of their lands in France in 1789 after the French Revolution hit the Knights hard, however, and they readily capitulated to Napoleon when he invaded in 1798. According to Thornton $(1836)^{8}$, the Università was insolvent even before the arrival of the French, with a deficiency of capital equal to $1,230,098$ scudi. This meant that more loans were needed: 233,047 at 6 per cent interest, and 997,051 at 3 per cent interest, thus giving an annual charge of 43,894 scudi. Despite aid from the Grandmaster in the form of an excise on wine, which brought in 28,500 scudi, this still amounted to a considerable indirect tax through the price of bread.

\subsection{The transition to British rule}

In 1798, Napoleon conquered Malta. A two-year siege of Valletta by the British ensued during which the French garrison depleted the Massa Frumentaria, taking 1,203,660 scudi. ${ }^{9}$ After an uprising by the Maltese in 1799 Britain took the island under its protection. The first years of the British occupation are well documented by Gregory (1996). ${ }^{10}$

\footnotetext{
${ }^{6}$ Mea, J., 'Customs Tariff in Malta since 1530', Journal of the Maltese Historical Society, vol.2, no.2, 8894.

${ }^{7}$ Pirotta, 1996.

${ }^{8}$ Thornton, W.H., Memoir of the Finances of Malta, Under the Government of the Order of St John of Jerusalem, During the Last Years of its Dominion, and as Compared with those of the Present Time, Malta, 1836. 33

${ }^{9}$ Ibid., 34.

${ }^{10}$ Gregory, D., Malta, Britain and the European Powers, 1793-1815, London, 1996.
} 
The British found just eight days supply of grain left when they took over. As an emergency measure, the British Treasury first paid for large imports, so that already by 6 March 1801 there was enough grain to last until December the following year. However, after this the British generally resisted active participation in the grain trade, and simply restored the institutions that had been present under the knights, including the Università. This might be explained by the British being sceptical as to the value of the island and expecting that their occupation would only be temporary. ${ }^{11}$ Indeed, it was many years and rounds of international negotiation before it became clear that the Knights were not to return.

Besides, the regulation of the grain trade was not at this time as anathema to the British as it was later to be. The British Corn Laws, although effectively inoperative until the end of the Napoleonic Wars in 1815, had otherwise regulated the British supply of wheat for centuries, and there was a general acceptance that regulation was necessary for price stability. So it should not come as a surprise to find the adviser to the British Civil Commissioner in Malta, William Eton, writing in 1807 that it was important that the present system be maintained. He noted that with low grain prices people "drank more wine" leading to them becoming "idle and dissipated". If prices then became high, people were then not able to work harder and "great misery and discontent ensued". Constant, rather high, prices were of utmost importance: "When the prices became stationary, they could proportion their means of earning and their mode of living to their expenses, which they could exactly ascertain. And it was found, that moderately high prices encouraged industry by perpetuating a habit of assiduity, first called into action by necessity. Too low prices produced the opposite effect." 12

Although the Università was left heavily in debt after the French occupation, these debts had been assumed by the British government. The British recapitalized the Università and constructed new granaries. ${ }^{13}$ However, in 1812 Royal Commissioners discovered that it was again badly in debt, largely due to maladministration. When the Plague came to Malta (from May 1813 to January 1814), the island was cut off, and the Università's debt increased even more.

The Commission did not, however, recommend dismantling the monopoly, and the Colonial Secretary reluctantly agreed to maintain the Università, partly because this had been promised to the Maltese over the years. ${ }^{14}$

\subsection{Under British rule}

In July 1813 Britain annexed Malta, and in May 1814 the Treaty of Paris was signed, acknowledging British sovereignty over Malta, which remained a Crown Colony of the

\footnotetext{
${ }^{11}$ Busuttil, S., ‘An Overview of Malta's Economic Development', in V. Mallia Milanes (ed.), The British Colonial Experience 1800-1964, Malta, 1988. 155-156

${ }^{12}$ Eton, W., Authentic Materials for a History of the People of Malta, London, 1807.

13 Thornton, 62.

${ }^{14}$ Pirotta, 96.
} 
British Empire until 1964. It took four years for this to bring institutional changes to the grain trade.

By 1814 the government had lost $£ 60,000$ and in 1818 the duties of the Università were given to the new Commissioners of a Board of Supply. When this failed to bring improvement, the Università was abolished and the trade in grain was opened up in 1822 after a campaign by Maltese merchants. Private commercial interests took over the import of grain under a system of open competition. A Grain Department under a Superintendent was established which was independent of the Collector of Sea Customs. The Grain Department was divided into two branches: the Government Grain Concern and the Revenue Branch. The former was responsible for purchases abroad and for local sales, and the latter collected the consumption duties and the store rent.

The government's new role was then as follows: first, to reserve a stock of wheat to guard against scarcity and high prices; and second, to charge a duty of four scudi per salm for wheat carried by British or Ionian vessels, and five scudi per salm for wheat imported in other ships. Additionally, on importation there was a Custom House Duty of 1 per cent ad valorem. These duties were intended to cover the expenses of maintaining the reserve stock, and to finance the government. It has been suggested that the duty of four scudi was inspired by the difference between the purchase and sales prices of wheat of 20 and 24 respectively under the Università before $1793 .{ }^{15}$

In the $1820 \mathrm{~s}$ and $1830 \mathrm{~s}$, Malta seems to have mirrored many of the institutional changes adopted in the UK, but in actual fact the reforms in Malta preceded those of the mother country. So, from June 1824 goods were admitted in bond and a sliding scale of duties, varying monthly with the prices, was imposed by the Collector of Customs. A similar system was adopted for the UK in 1828 .

The 1824 sliding scale stated that duties were to be levied on Egyptian wheat if imported under the British or Ionian flag as follows:

\begin{tabular}{|l|l|}
\hline $\begin{array}{l}\text { When the average price } \\
\text { of Egyptian wheat per } \\
\text { salm was... }\end{array}$ & $\begin{array}{l}\ldots \text { the duty } \\
\text { was... }\end{array}$ \\
\hline Under 25 shillings & $10 \mathrm{~s}$. \\
\hline Above 25 shillings & $8 \mathrm{~s} .4 \mathrm{~d}$. \\
\hline Above 33 shillings & $6 \mathrm{~s} .8 \mathrm{~d}$. \\
\hline Above 42 shillings & $5 \mathrm{~s}$. \\
\hline Above 50 shillings & $3 \mathrm{~s} .4 \mathrm{~d}$. \\
\hline At 58 shillings and & $1 \mathrm{~s} .8 \mathrm{~d}$. \\
\hline
\end{tabular}

${ }^{15}$ Mea, 89. 
under 67 shillings

Wheat from other countries was however subject to the following scale:

\begin{tabular}{|l|l|}
\hline $\begin{array}{l}\text { When the average price } \\
\text { of Egyptian wheat per } \\
\text { salm was... }\end{array}$ & $\begin{array}{l}\ldots \text { the duty } \\
\text { was... }\end{array}$ \\
\hline Under 25 shillings & $13 \mathrm{~s} .4 \mathrm{~d}$. \\
\hline Above 25 shillings & $11 \mathrm{~s} .8 \mathrm{~d}$. \\
\hline Above 33 shillings & $10 \mathrm{~s}$. \\
\hline Above 42 shillings & $8 \mathrm{~s} .4 \mathrm{~d}$. \\
\hline Above 50 shillings & $6 \mathrm{~s} .8 \mathrm{~d}$. \\
\hline Above 58 shillings & $5 \mathrm{~s}$. \\
\hline Above 67 shillings & $1 \mathrm{~s} .8 \mathrm{~d}$. \\
\hline
\end{tabular}

Moreover, a protecting duty of $1 \mathrm{~s}$. $8 \mathrm{~d}$. per salm was imposed on importation under the foreign flag when released for consumption.

Administrators, when considering the reform of the tariffs which was to come into effect in 1832, noted the special dependence of Malta on foreign food supplies for "twothirds of their food" and that the "first care of the government must be to extend the intercourse with foreign countries". ${ }^{16}$ However, it was recognized that attempts to tax more luxury goods were futile, both because of the small consumption of these goods, and because of the difficulties in preventing smuggling. The reforms thus simply removed the link of wheat duties to the Egyptian price of wheat (Egypt had stopped supplying grain), reduced the expense due to bonding of grain, and attempted to promote trade with British shipping. ${ }^{17}$ The 1 per cent ad valorem Custom House duty on import was also abolished.

\footnotetext{
16 Thornton, 67.

${ }^{17}$ Ibid., 73.
} 
The sliding scale from December 1832 was as follows:

\begin{tabular}{|l|l|}
\hline $\begin{array}{l}\text { When the average price } \\
\text { of foreign wheat per } \\
\text { salm was... }\end{array}$ & $\begin{array}{l}\ldots \text { the duty } \\
\text { was... }\end{array}$ \\
\hline At or under 25s. & $12 \mathrm{~s}$. \\
\hline Above 25s. & $11 \mathrm{~s}$. \\
\hline Above 30s. & $10 \mathrm{~s}$. \\
\hline Above 35s. & $9 \mathrm{~s}$. \\
\hline Above 40s. & $8 \mathrm{~s}$. \\
\hline Above 45s. & $7 \mathrm{~s}$. \\
\hline Above 50s. & $6 \mathrm{~s}$. \\
\hline Above 55s. & $5 \mathrm{~s}$. \\
\hline Above 60s. & $3 \mathrm{~s}$. \\
\hline \multicolumn{1}{|c|}{ Above 65s. } & \\
\hline
\end{tabular}

Additional rates were payable on importation by foreign vessels: If the average price was under $45 \mathrm{~s}$., this should be $2 \mathrm{~s}$. "within the Mediterranean from Gibraltar to the Dandanelles" or 2s. 6d. "without the Mediterranean". If the average price was between 45 and 50 shillings, it should be 1s. "within" and 1s. 3d. "without".

Under the recommendations of the Austin Commission ${ }^{18}$, a major reform of tariff law was enacted in 1837. This abolished almost all other duties on imports in Malta, except those on other grains, pulses and seeds, alcohol, some sorts of animals, charcoal and vinegar. ${ }^{19}$ It was thus a very liberal reform which predated the repeal of the Corn Laws in 1846 and the movement to free trade in the UK and the rest of Europe by a decade.

In terms of wheat, however, the reforms were less liberal. The reserve stock was abandoned, and the Grain Department was closed down. But the sliding scale was simply

\footnotetext{
${ }^{18}$ To investigate "How the resolution to discontinue the Government interference with the corn trade of Malta can be carried into execution most effectually, and with the least temporary inconvenience or distress to the parties who will be more immediately affected by the measure".

${ }_{19}$ MacGregor, J., Commercial Statistics. A digest of the productive resources, commercial legislation, customs tariffs, navigation, port, and quarantine laws, and charges, shipping, imports and exports, and the monies, and measures of all nations. Including all British commercial treaties with foreign states, Vol.1, London, 1844, 1267-1268.
} 
replaced by a fixed duty of 10 shillings per salm, independent of the national origins of the importing ship. This rate was somewhere between the old preferential and foreign tariff rates and was close to the average duty under the sliding scale from 1833 to 1836 of $10 \mathrm{~s} 3.75 \mathrm{~d}$. (Porter 1851, p. 732) This fixed duty remained in force from 1837 to $1935 .^{20}$

The importance of the regulation of the grain trade thus remained for a long time into the twentieth century. Sette Giugno is a Maltese National Day, and commemorates events which happened on 7 June 1919. Riots ensued after the authorities raised the price of bread during which British troops fired into the crowds, killing four people. This would hasten the movement to self government, with the first Maltese Parliament inaugurated under the new constitution of 1921. Even under self-government, however, the grain tax was to remain the main source of government revenue until the introduction of income $\operatorname{tax}$ in $1948 .^{21}$

Of course, many people in Britain wondered how a system based on taxing grain - so abhorrent in the mother country - could be allowed to continue. On recommending more focus on education in Malta, a British Commission suggested that "If these elementary truths had been generally understood by the inhabitants, the economical interests of the island would have been saved from many of the evils which the ignorance of its former Governments inflicted upon them; for example, they would not have been visited with the Government monopoly of corn; with the subsequent intervention of the Government in the corn trade of the island; with long and complicated tariffs needlessly shackling its general commerce...". ${ }^{22}$ But despite these occasional protests from free traders in Britain there was no change.

So, although it is sometimes assumed that Malta followed the free-trade philosophy of Britain $^{23}$, the above account shows that this was assuredly not the case. Malta liberalized early, but on the other hand maintained high tariffs on grain. The difference between Malta and Britain was that the former did not rely on the Corn Laws for tariff revenues, but in Malta the government remained heavily dependent on the duty on grain, which accounted for about a third of total revenue.

\section{Impact of the grain duties}

Figure 2 illustrates the price of wheat in Britain and in Malta. For the years until 1822, data is available for the price at which the monopoly purchased wheat, and that at which it sold wheat. After this date, the prices for Malta are the price paid by consumers, including the duty.

\footnotetext{
${ }^{20}$ In 1935 the duty was first reduced and then, in 1939, replaced by a system again giving preferential rates to British ships.

${ }^{21}$ Pirottta, 158.

${ }^{22}$ BPP, 1837, Copies or extracts of reports of the commissioners appointed to inquire into the affairs of the island of Malta, and of correspondence thereupon, Part 1, 126.

23 Atkins, P.J. and Gastoni, M., 'The Maltese food system and the Mediterranean', Geojournal, vol.41, no.2, 127-136 (130)..
} 


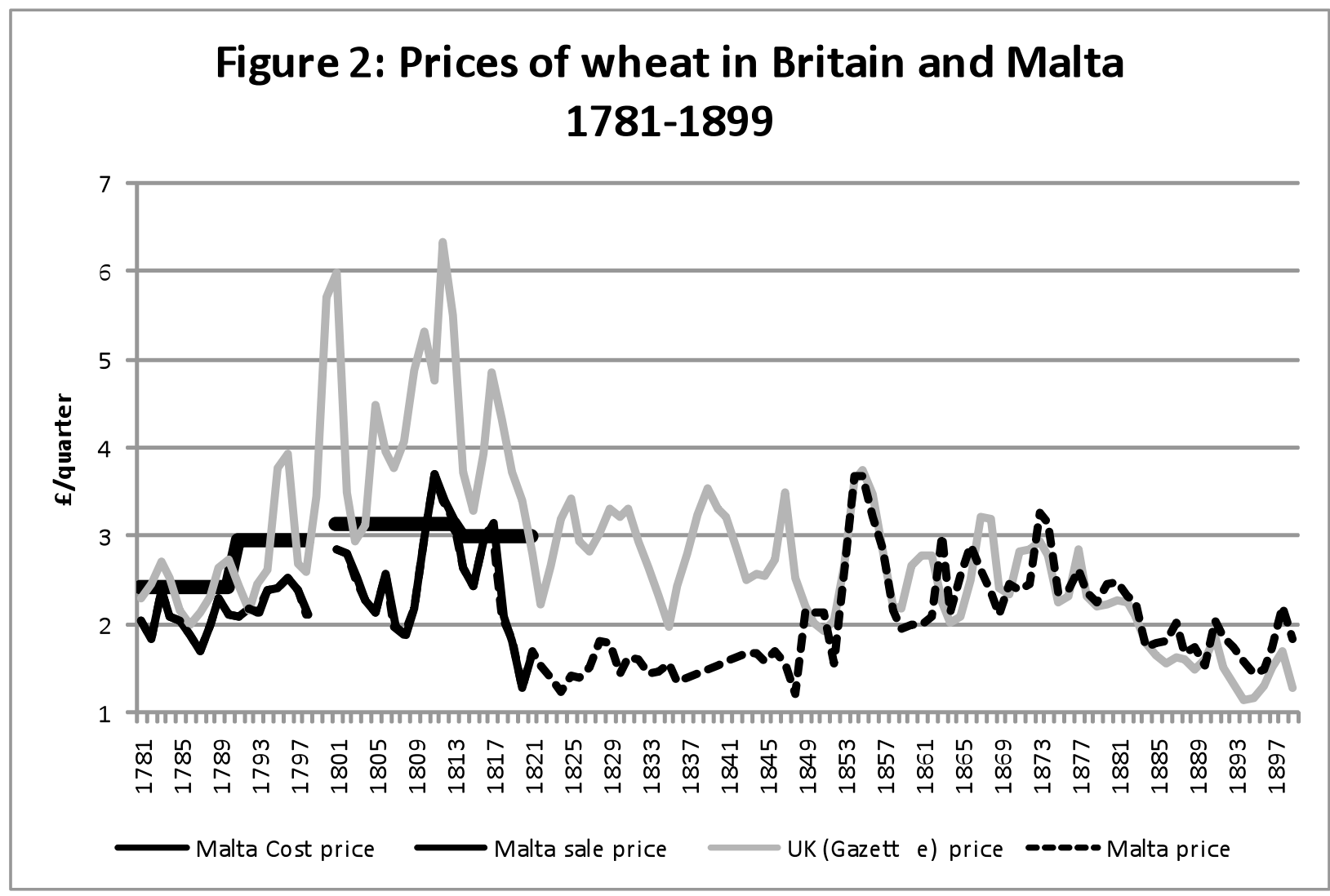

Sources: BPP(various). No price data for Malta is available for the years of the French occupation (1799-1800). Likewise, it has been impossible to find data for the years 182223 and 1837-42. Here linear interpolation has been used to fill the gaps. For 1876-1899 an average of the low and high values recorded in the Statistical Tables has been used.

Clearly, the financial difficulties of the knights and the Università led to them charging a far higher price for wheat than that which they paid for it, although the difference is less marked under the British. In general, however, the Maltese were consuming much cheaper wheat than the British, until the British liberalized the grain trade in the second half of the nineteenth century, and the situation is reversed. The changes in the price gap can better be understood by calculating the AVEs of the duties on wheat.

Figure 3 illustrates the level of the AVEs of the Maltese duties on wheat from the time of the knights until the end of the nineteenth century. From 1824 they are calculated using the method described in Sharp (2006), i.e. total revenue, divided by the value of imports. Under the monopoly, data is available for the purchase and sales price of wheat, and the AVE is then estimated by expressing the difference between these prices as a percentage of the cost price. This means, of course, that negative AVEs will be implied if the fixed sales price was under the cost price, as it was for a few years. 


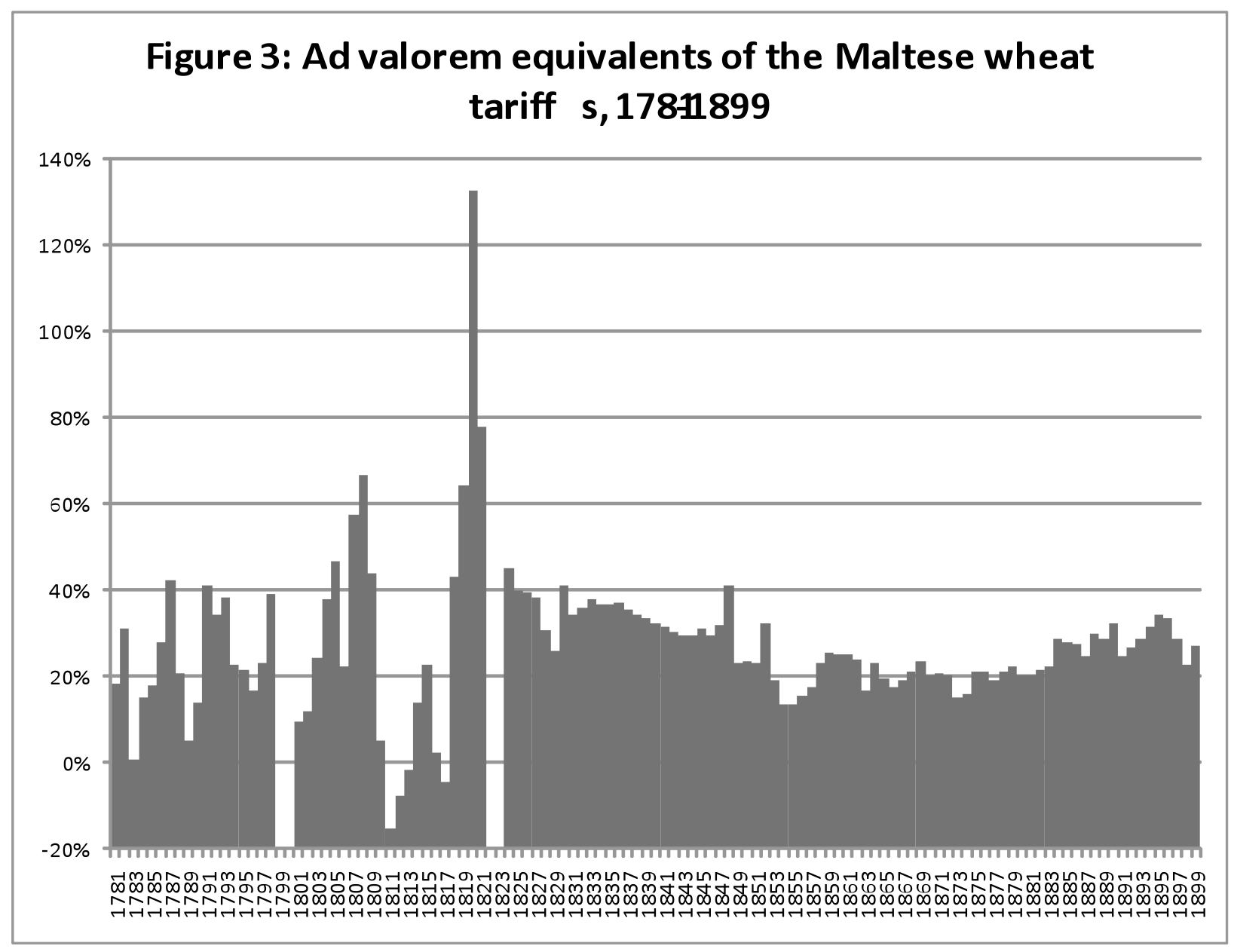

Sources: BPP(various), own calculations. Since prices are not available for 1799-1800, and the duties received are not available for 1822-23, there are no estimates for these years.

Overall the picture is one of not much change from the time of the knights to the period under British rule. Prices fell substantially after the Napoleonic wars, hence the spike due to the sales price not following suit. The AVEs after the abolition of the monopoly are surprisingly constant, however.

The contrast between the experience of Malta and Britain is illustrated in figure 4, where the UK AVEs are taken from Sharp (2006). The point is clear: Malta did not follow the free trade ideology of Britain, at least in terms of wheat. 


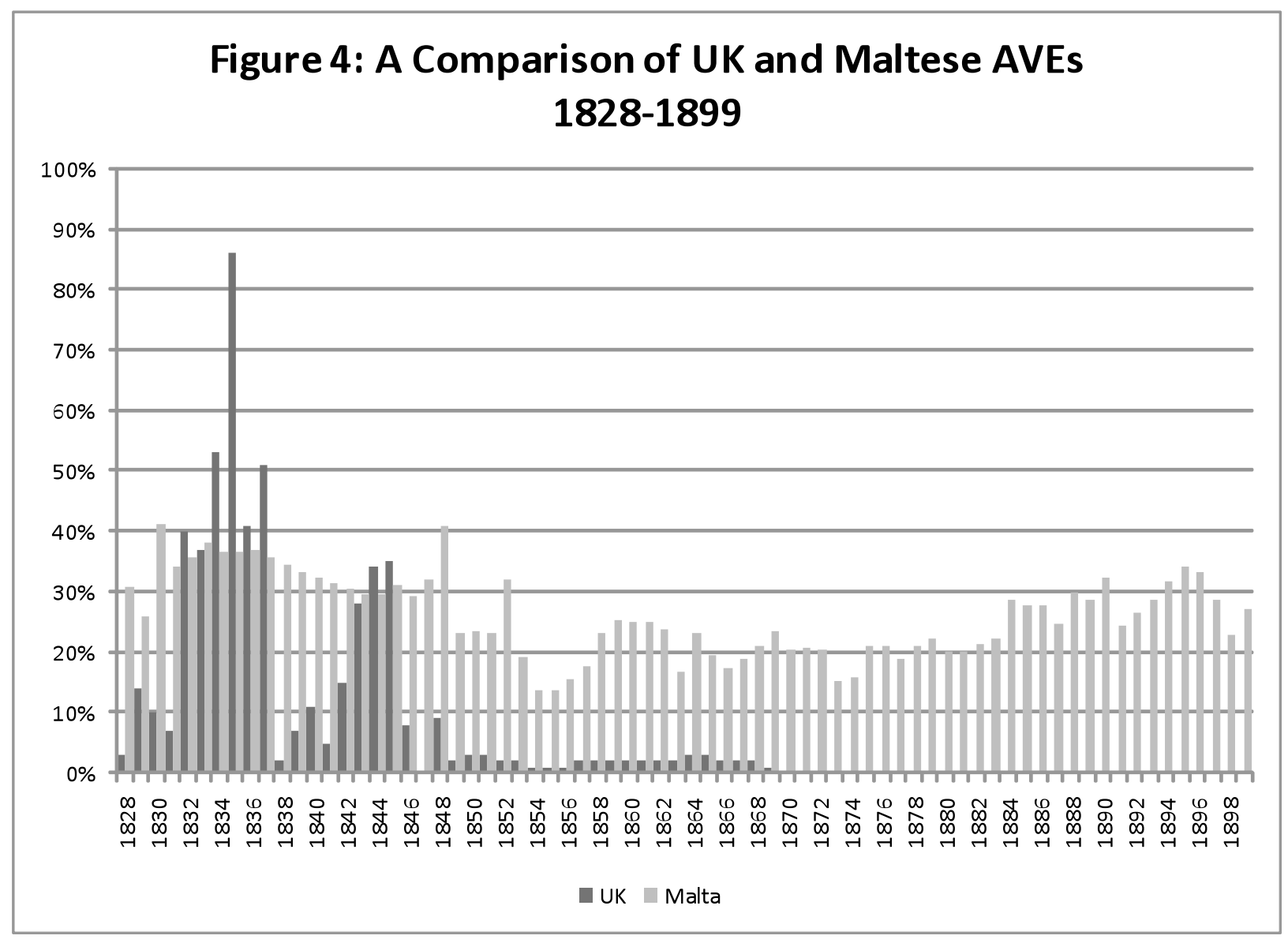

Sources: As figure 3, Sharp (2006).

Finally, figure 5 illustrates the price differential between Maltese and UK wheat as a percentage of the price of UK wheat. This is of course simply another way of visualising the data in figure 2. Until the repeal of the UK Corn Laws, Maltese wheat was cheaper than that in the UK - spectacularly so with the protection afforded to UK agriculture by the Napoleonic Wars and the subsequent reforms of the Corn Laws. This early relative liberalism did not last, however, and the Maltese were to become relatively "protectionist" in the second half of the nineteenth century, reflected in a higher relative price of Maltese wheat after the late 1840s. There was, however, little agriculture to protect, so this was less protectionism than a maintenance of revenue raising tariffs. The UK, for example, also kept high tariffs, ostensibly for revenue purposes, on wine, for example. 


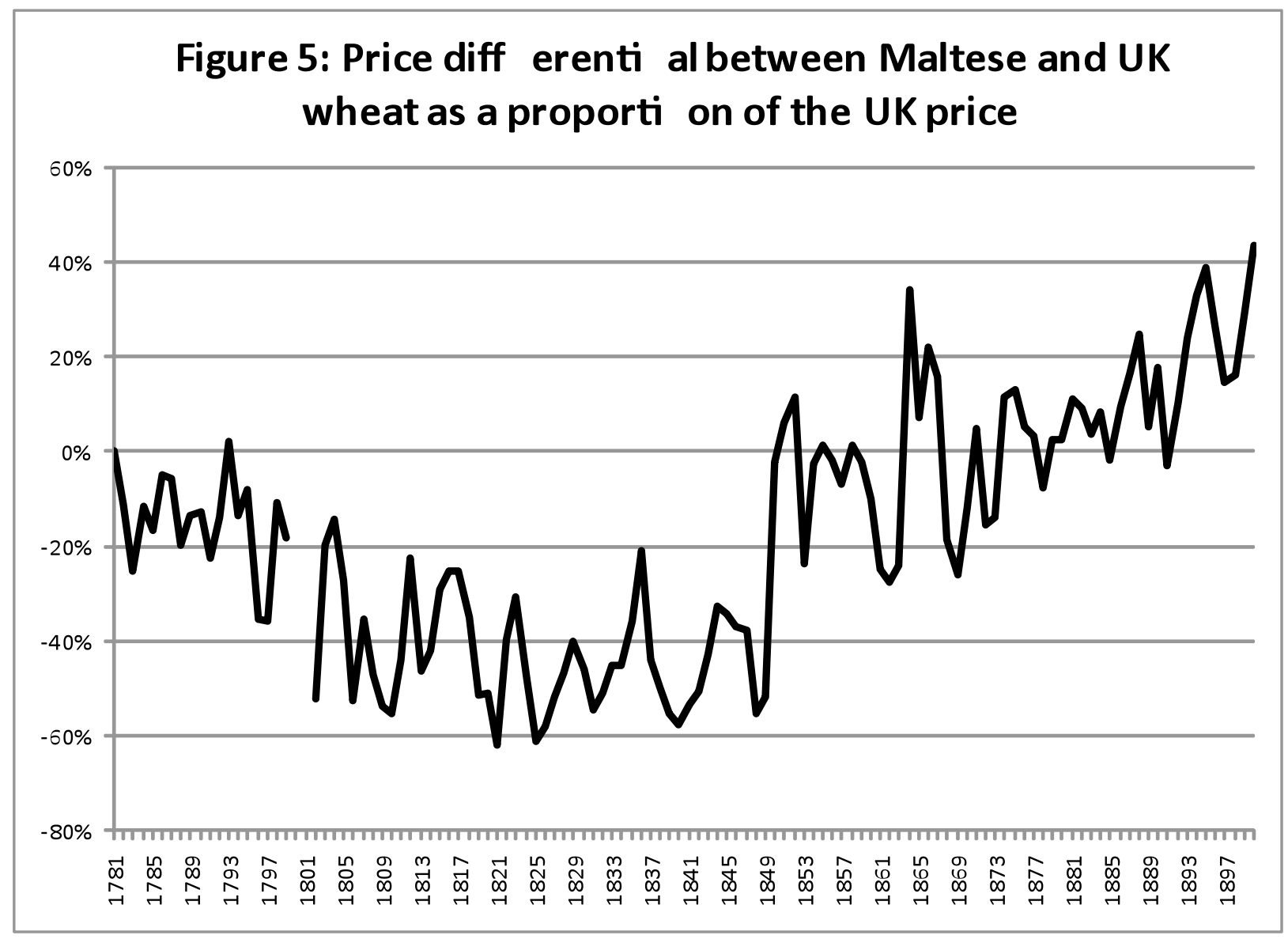

Sources: See figure 2.

The maintenance of this level of duties had consequences of course. They led to an increase in the price of bread in comparison to other nearby countries, as documented in the British Parliamentary Paper (1878). The same report concludes that due to the intrinsically regressive nature of the duties on wheat, the incidence of taxation was $10 \mathrm{~s}$. 10d. per head per annum for the 37 thousand "Maltese upper and middle class" (5s. for wheat alone), but $15 \mathrm{~s} .7 \mathrm{~d}$. per head per annum for the 112 thousand "Maltese working class" (10s. for wheat alone). ${ }^{24}$ Although this might seem counterintuitive, it is described how "Bread or paste constitutes almost the sole food of the working class, who rarely eat meat". It is thus assumed that the richer classes were consuming less wheat per capita, and therefore presumably more of other foodstuffs such as fish and meat, as well as using a greater proportion of their income on manufactures, which were not taxed.

Of course, if the Maltese government had been redistributing this wealth back to the poorest in society, this would not have been an unfair burden on the poor, but, in common with other countries at the time, the majority of the revenue went on administration, and then on public goods such as roads and policing which were of use to

${ }^{24}$ BPP 1878, Malta Correspondence respecting the taxation and expenditure of Malta, 15. 
rich and poor alike. ${ }^{25}$ Could the Maltese government have raised the necessary revenue in any other way? As discussed above, they clearly did not believe so. However, the island was also, for example, a large importer of manufactures, the value of which even by 1835 , exceed that of imports of grain. ${ }^{26}$ Here, however, politics might have played a role, since presumably this would have met opposition from Britain as well as from Maltese importers and middle class consumers.

\section{Conclusion}

The arrival of the British changed little as regards the duties afforded to wheat in Malta. Even after the onset of a radical free trade ideology in the motherland in the 1840s, and an early movement to trade liberalization, Malta continued to levy a duty of 20-30 per cent of the value of wheat. Successive administrations failed to reform this, because the Maltese government was so dependent on the revenue from the grain trade. This was then the crucial difference between the UK and Malta. In the UK, the Corn Laws were in part a product of ideology, protecting landed interests. In Malta there was little landed interest to protect. Instead, the administrations made use for revenue reasons of an inelastic demand for imports of foodstuffs and wheat in particular by a population which was unable to supply itself. ${ }^{27}$ Whether alternative methods of financing might have been possible, it is beyond the scope of this paper to say. What is clear, however, is that these duties hurt the poorest in society and made Malta an outsider in the first free trade era.

Note - Data Sources: BPP (various). Statistical tables relating to the Colonial and Other Possessions of the United Kingdom; Malta Blue Books: available online at http://www.nso.gov.mt/site/page.aspx?pageid=392

\section{Appendix: A note on the historical currency and units of measure of Malta}

The salma (plural salme), sometimes written in English as salm, was a Maltese unit of volume, and was $98.5 \%$ of an imperial quarter, i.e. 286.59 litres. From 1875 it was declared exactly equal to an imperial quarter, i.e. 290.95 litres.

The silver scudo (plural scudi) was the currency of Malta until 1798, and remained in circulation until 1825 , when it was replaced by the British pound at the rate of $£ 1=12$ scudi. It was subdivided into 12 tari (singular taro), each of 20 grani with 6 piccioli to the grano. The exchange rates used here are those given by Mallia-Milanes $(1988$, p. 135), i.e. $£ 0.1$ to the scudo from 1781 until 1798, and $£ 0.083$ to the scudo from 1801 until its replacement by the pound in 1825. The UK pound (£) was equal to 20 shillings (s.), which were equal to 12 pennies (d.).

See MacGregor (1844, pp. 1273-1275) for more on the historical currency, weights and measures of Malta.

\footnotetext{
${ }^{25}$ Thornton, 75; BPP 1878, 5-6.

${ }^{26}$ MacGregor, 1844, 1271.

27 Although, as a referee noted, the statement by William Eton from 1807 quoted above does suggest that there were also ideological reasons for grain price regulation.
} 
Journal of Maltese History Volume 1 Number 2, 2009 